\title{
Õppetöö planeerimise oskuste modelleerimine ja küsimustiku väljatöötamine planeerimistegevuse uurimiseks
}

\author{
Ingrid Konia $^{\text {a }}$, Edgar Krull ${ }^{\mathbf{a}}$ \\ a Tartu Ülikooli haridusteaduste instituut
}

\begin{abstract}
Annotatsioon
Eduka õpetajatöö üks olulisi eeldusi on õppetöö planeerimise oskus, mille jaoks on vajalikud nii teoreetilised kui ka praktilised teadmised. Paraku on õppetöö planeerimise uurimine osutunud teadlastele üsna keeruliseks ülesandeks. Ühelt poolt on selle põhjus planeerimise kui protsessi enda keerulisus, teisalt aga tõdemus, et kõike pole võimalik planeerida. Uurimuse eesmärk oli luua usaldusväärne küsimustik õpetajate planeerimisoskuste uurimiseks. Teoreetilise mudeli loomisel tugineti formaalse teadmisena Gage’i ja Berlineri (1998) õpetamise põhiülesannete mudelile ning õpetaja mõtlemisprotsesside avaldumisele kolmes õppetöö etapis (Eggen \& Kauchak, 2013). Selle tulemusena koosneb küsimustik viiest suuremast teemavaldkonnast, milleks on eesmärkide määratlemine, õpilaste/klassi eripära arvestamine, õppimise ja motivatsiooni mõistmine ning saadud teadmiste rakendamine, õppemeetodite väljavalimine ja rakendamine ning õpitulemuste hindamine. Iga valdkonna küsimused on püstitatud mudeli alusel ja esitatud Likert-tüüpi viiepallilistel skaaladel.
\end{abstract}

Võtmesõnad: õppetöö planeerimine, õppetöö planeerimise modelleerimine, õpetajakoolitus, algajad õpetajad, meisterõpetajad

1 Haridusteaduste instituut, sotsiaal- ja haridusteaduskond, Tartu Ülikool, Salme 1a, 50103 Tartu, ingrid.koni@ut.ee 


\section{Sissejuhatus}

Õpetajatöö üks olulisemaid komponente on ainekursuste ja tundide planeerimine. Oma igapäevatöös vastutavad õpetajad selle eest, et nende õpilased õpiksid vastavuses õppekava nõuete ja ühiskonna ootustega. Selleks peab õpetaja olema valmis arvestama ópilaste vajaduste ja huvidega ning andma endast kõik, et õppimine toimuks ka kõige ebasoodsamates tingimustes. Et see õnnestuks, vajab õpetaja oskust õppetööd planeerida (Yinger \& Hendricks-Lee, 1998).

Õppetöö planeerimine nõuab õpetajalt nii teoreetilisi kui ka praktilisi teadmisi ja oskusi. Et planeerimistööks vajalikke teadmisi ja oskusi saaks hõlpsamini edastada algajatele õpetajatele, on tarvis keskenduda kõige olulisemale. See eeldab õppetöö planeerimise põhitõdede väljaselgitamist ja nende põhjal õppetöö põhitegevuste modelleerimist teadusuuringutega. Kuna õppetöö planeerimine on komplitseeritud ja mitmetahuline protsess, on ka selle uurimine ja modelleerimine osutunud teadlastele üsna keeruliseks ülesandeks. Uurimist raskendab ka asjaolu, et õpetajad ei järgi planeerimisel ühetaolisi mudeleid ja mustreid ning sageli ka ei teadvusta selle kõiki detaile. Pealegi on reaalses klassis toimuv tihti ettearvamatu ning seega täies mahus planeerimatu (Yinger \& Hendricks-Lee, 1998), mistõttu kogenud õpetajad ei koosta sageli kirjalikke tunnikavandeid (Kansanen, 1981). See tähendab, et kogenud õpetajad ei püüagi detailselt planeerida tunnis toimuvat, kuivõrd reaalne tegevus kujuneb välja interaktsioonis õpilastega ja seda ei saagi alati täpselt ette näha. Ebamäärane piirjoon selle vahel, mis on reaalselt planeeritav ja mis pole, komplitseerib veelgi õpetajate planeerimisoskuste uurimist.

Senised uurimused näitavad, et õppetöö planeerimise protsessis saab eristada mitmeid tasandeid ning neid klassifitseeritakse erinevatelt lähtealustelt. Clarki ja Yingeri (1987) käsitluse kohaselt võib planeerimistoiminguid klassifitseerida ajalisest ja korralduslikust aspektist lähtudes. Nende metaanalüüsi järgi võib planeerimise ajalises dimensioonis eristada õppetöö kavandamist aastaks, semestriks, nädalaks ja tundideks. Korralduslikust aspektist osutavad autorid ülesannetele, mida tuleb õpetajal täita õppetöö erinevatel etappidel, nt õppeaasta alguses klassi füüsilise keskkonna kujundamine, õpilaste võimete väljaselgitamine ning klassi kui sotsiaalse terviku kujundamine. Artiklis keskendutakse õppetöö planeerimise protsessi kirjeldamisel ajalisele jaotusele (eristades vahetut óppetöö planeerimist tundideks ja õppetöö planeerimist kursuseks), kuid vaatluse alla võetakse ka korralduslikud ülesanded, mis õpetajal tuleb sooritada õppetöö õnnestumiseks.

Õppetöö planeerimisel lühemaks perioodiks tuleb eristada õppetunni ja õppeühiku mõistet. Nende põhimõtteline erinevus seisneb selles, kas õppetöö 
ühikut määratletakse kestusena või õpitud sisu järgi. Õppetundi, nagu see on olnud käibel Comeniusest peale, defineeritakse kui kindla kestusega õppetöö ühikut, mille vältel õppetöö toimub. Õppeühikut defineeritakse kui õppeeesmärkide saavutamiseks vajalike õpitegevuste järgnevust. Õppeühik võib koosneda mitmest õppetunnist (Gagné \& Driscoll, 1992). Eesti üldhariduskoolides on õppetunni kestus tavaliselt 45 minutit. Artiklis lähtutakse õppetöö planeerimise protsessi määratlemisel ajalisest aspektist, mille raames keskendutakse detailsemalt nii lühiajalisele planeerimisele, mis hõlmab üksiktunni või mitme järjestikuse üksiktunni planeerimist terviku teemana, kui ka pikaajalisele planeerimisele, mis hõlmab terve kursuse planeerimist.

Uurimuse eesmärk oli koostada küsimustik algajate (ka õpetajakoolituse üliõpilaste) ja meisterõpetajate planeerimisoskuste uurimiseks. Et küsimustikuga oleksid haaratud kõik planeerimisprotsessi olulisemad tahud, antakse varasemate uurimuste põhjal ülevaade planeerimisprotsessiga seonduvatest põhielementidest. Küsimustikuga kogutud andmestik loob eeldused algajate ja meisterõpetajate õppetöö planeerimise oskuste hindamiseks ning võrdlemiseks. Erinevuste väljaselgitamine võimaldab omakorda algajate õpetajate õppetöö planeerimise oskusi sihipäraselt arendada.

\section{Ülevaade õppetöö planeerimise käsitustest ja uurimustest}

Üks põhjalikumaid õpetaja planeerimistegevuse uurimuste metaanalüüse pärineb Yingerilt ja Hendricks-Leelt (1998). Nende analüüs kajastab planeerimisalaseid uurimusi arenguetappidena uurimismetodoloogias. Oma artiklis kujutavad nad arengulisi nihkeid liikumisena õppetöö planeerimise tehniliselt kontseptsioonilt psühholoogilisele ja sellelt omakorda ökoloogilisele käsitlusele.

Õppetöö planeerimise tehnilise kontseptsiooni kohaselt (Yinger \& Hendricks-Lee, 1998) toetusid õpetajate planeerimisoskuste uurimused enne 1970ndaid teooriast praktikasse liikumise paradigmale. Sellised õppetöö planeerimist kirjeldavad mudelid nägid planeerimist nelja järjestikuse etapi läbimisena: a) eesmärkide kindlaksmääramine, b) õpitegevuste väljavalimine, c) õpitegevuste organiseerimine ning d) hindamisprotseduuride kindlaksmääramine (nt Tyler, 1949). Sedalaadi mudelite lähtealuseks oli arusaam, et õpilase õppimine on õpetaja kontrolli all. Selline arusaam oli eriti levinud 1950.-1960. aastail.

Alates 1970ndatest tehtud uurimused tõestasid, et õpetajad üldjuhul ei järgi õppetöö planeerimisel sedalaadi mudeleid. Pigem näitasid need uurimused, et õpetaja mõtleb tundide planeerimisel eeskätt aine sisule, õpitegevuste või õpilaste eripärale, mitte konkreetselt püstitatud eesmärkidele. 
Kuna samal ajal jätkus jõudsasti kognitiivse psühholoogia võidukäik õppimise ja õpetamisprotsesside käsitlemisel, tunti uurimustes üha rohkem huvi õpetaja mõtlemisprotsesside vastu, mis rakenduvad õppetöö planeerimise käigus. Pealegi selgus uurimustest, et planeerimine kui tegevus sõltub kontekstist, milles õppetöö toimub, ning see omakorda õppetöö planeeritavast kestusest (aasta, nädal või üks tund) (Yinger \& Hendricks-Lee, 1998).

Eelkirjeldatu põhjal järeldas Yinger (1980), et õppetöö planeerimine on pigem tsükliline ja kirjeldatav mudelina, mis kujutab planeerimist kui eesmärkide ja tegevuste järkjärgulist määratlemist. Konkreetses planeerimistegevuses tugineb õpetaja oma varasematele teadmistele õnnestumistest ja läbikukkumistest ning oskusele häälestada õpetamine nii, et see vastaks õpilaste vajadustele ja oskustele (Yinger \& Hendricks-Lee, 1998).

1980ndad tõid õppetöö planeerimise uurimisse uued suunad. Enam ei piirdutud õpetaja individuaalsete psühholoogiliste protsessidega, vaid võeti arvesse ka õppetöös ilmneva interaktsiooni mõju. Neist uurimustest kasvas välja tõdemus, et klassis aset leidev interaktsioon õpetaja ja õpilaste vahel on sageli õpetajale ettearvamatu ning seetõttu ka suures osas enne õppetööd planeerimatu (Yinger \& Hendricks-Lee, 1998). Planeerimine saab anda vaid raamistiku sündmustele, mis võivad õpetamise käigus aset leida, kuid tunnis, kus käivitub õpetaja ja õpilaste vahel interaktsioon, lükkub planeerimine tagaplaanile ning esmaseks saab õpetaja improvisatsioon (Yinger, 1987, viidatud Yinger \& Hendricks-Lee, 1998 j).

Kokkuvõttes saab öelda, et õppetöö planeerimise uurimuste orientatsioonides on toimunud nihked biheivioristlikelt käsitlustelt kognitiivsetele ning neilt omakorda sotsiaal-interaktsioonilistele, mis võimaldavad arvestada üha enam õpetamisega kaasnevaid loomulikke olusid, õpetaja enda tunnetusprotsesse ning klassis toimuvat interaktsiooni.

\section{Õppetöö planeerimise modelleerimine}

Õppetöö planeerimise kui õpetaja eesmärgistatud tegevuse lahtimõtestamiseks on erinevaid võimalusi. Ühe võimalusena võib selle tegevuse piiritlemiseks eristada õpetajatöös kui tervikus kolme järjestikust etappi: tunni planeerimist, realiseerimist ja hindamist. Peale nende etappide eristamise on võimalik planeerimistegevuse avamiseks toetuda teistele õpetajatöö mudelitele, mis pakuvad õpetajatele teoreetilist tuge tundide planeerimise ja andmise mõtestamisel. Viimasel paarikümnel aastal on hakanud levima õpetajate kutseteadmiste, -oskuste ja -hoiakute, sealhulgas õppetöö planeerimisega seotud võimekuse avamine õpetajate praktilise teadmise kontseptsioonina, mille erinevates käsitlustes püütakse kirjeldada, mida õpetajad 
reaalselt teavad ja mõtlevad oma ainest ja selle õpetamisest ning kuidas nad neid teadmisi ja oskusi klassis rakendavad.

\section{Tunni planeerimine kui õppetöö esimene faas}

Õpetajatöö kolmeetapilise mudeli järgi on ainekursuste ja tundide planeerimine esimene etapp, millega õpetaja õppetöös kokku puutub ning millest ta oma tööd alustab. Sellele järgneb kavandatu realiseerimine ja läbiviidu hindamine, sh selle reflekteerimine. Planeerimist võib määratleda kui mõtteprotsesside jada, mis on aluseks õpetaja edasisele tegevusele realiseerimisetapis (Eggen \& Kauchak, 2013).

Õppetöö planeerimine nõuab õpetajalt lähtumist erinevatest asjaoludest: õppekava nõuetega arvestamist ja nende aluseksvõtmist üksiku tunni ning tundide seeria planeerimisel, aineteabe eesmärgistatud esitamist, klassi atmosfäri ja õpilaste taustaga arvestamist, oma ainevaldkonna õppeeesmärkide püstitamist (millest omakorda kujundatakse spetsiifilisemad eesmärgid), õpitegevuste planeerimist püstitatud eesmärkide saavutamiseks ning hindamismeetodite ja tehnoloogiliste võimalustega arvestamist õppetöös (Darling-Hammond, Hammerness, Grossman, Rust, \& Shulman, 2005). Need on siinkohal vaid mõned näited õppetööga seonduvatest asjaoludest ja mõjuteguritest, millega õpetajal tuleb õppetöö planeerimisel arvestada, kuid reaalne tegevus on veelgi nüansirikkam.

\section{Õppetöö planeerimine kui protsess Gage’i ja Berlineri õppeprotsessi mudeli kohaselt}

Selleks, et õpetamist kui protsessi paremini mõista, on uurijad välja pakkunud erinevaid õppeprotsessi kavandamise ja läbiviimise mudeleid, mis on detailsemad kui äsja kirjeldatud õpetajatöö kolmeetapiline mudel.

Gage’i ja Berlineri (1998) õpetamise põhiülesannete (primary tasks of instruction) mudeli järgi (vt joonis 1) vajab õpetaja tööga edukaks toimetulekuks teadmisi ja oskusi, kuidas määrata enne õpetamist kindlaks õppetöö eesmärgid ja mõista õpilaste eripära. Siinjuures on oluline märkida, et mudelis kujutatavaid õpetamisülesandeid ei saa selgepiiriliselt jaotada planeerimis-, läbiviimis- ja hindamisetappideks, vaid need on omavahel vastastikuses toimes nii ettenägevas kui ka tagasisidestavas tähenduses. Näiteks, õppetöö kavandamisel ei piirdu õpetaja mõtlemine vaid normatiivdokumentidest (õppekavast) tulenevate nõuete ega õpikust pärit arusaamaga, milleks peaksid tema õpilased olema õppetöös suutelised, vaid tema otsused on mõjutatud olemasolevast õpetamiskogemusest, sealjuures selle reflekteerimisest. Osa pedagoogilisi 


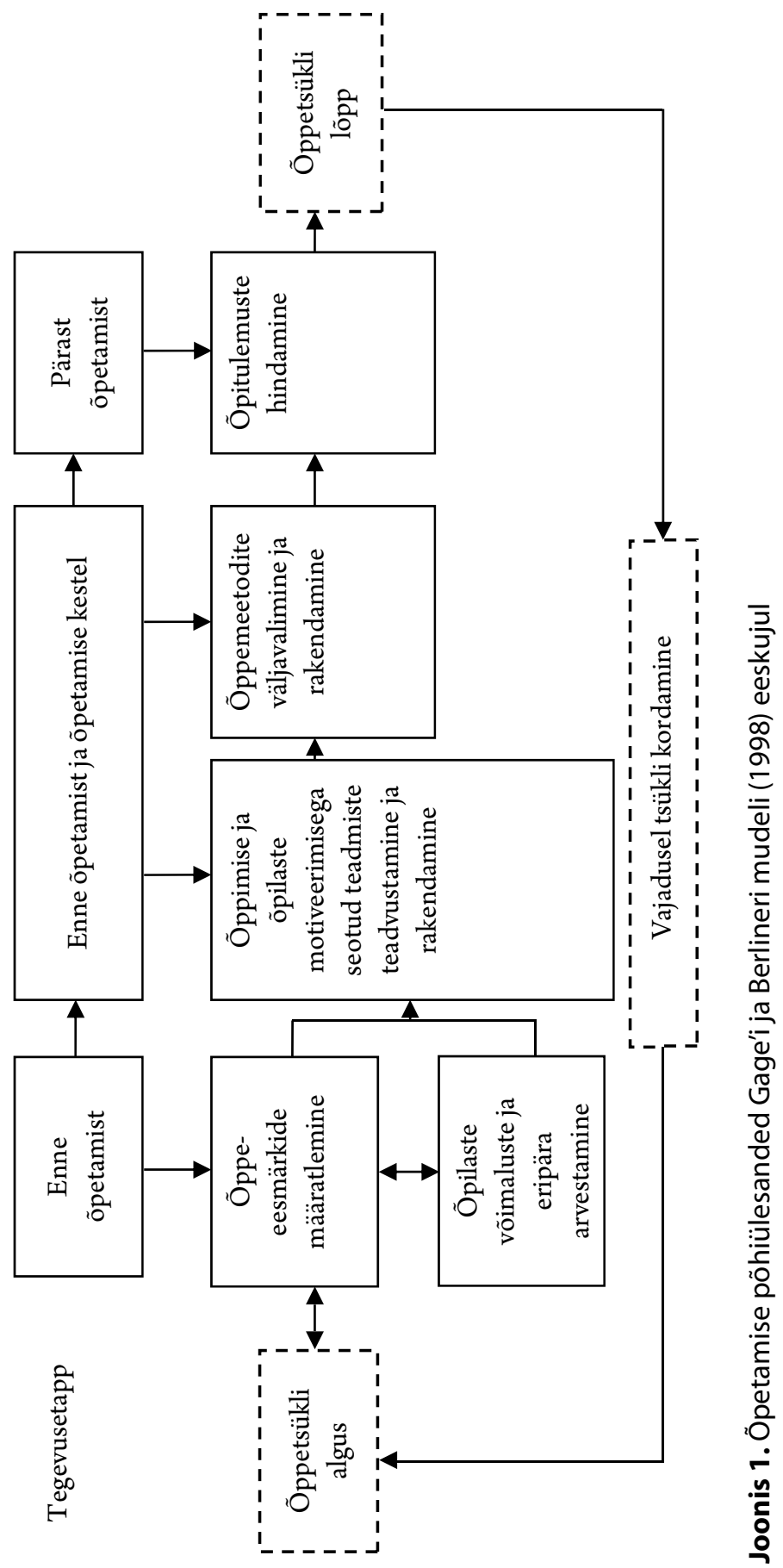


otsuseid langetabki õpetaja õpetamistegevuse käigus ja seetõttu on üsna keeruline piiritleda, kus lõpeb planeerimine ja algab õpetamine. Näiteks tuleb õpetajal arvestada enne õpetamist ja õpetamise kestel õppimise ja motivatsiooni kujunemise seaduspärasustega ning valida välja oludele vastavad konkreetsemad õpetamisviisid. Vaid tänu paindlikkusele planeerimisel ja õppetöö läbiviimisel saavutab õpetaja, et kasutatavad õppemeetodid ja üldine lähenemine klassile tagavad nii üksikõpilase kui ka terve klassi tahte ja suutlikkuse õppida. Pärast õpetamist annab hea õpetaja hinnangu õpilaste õpi- ja kasvatustulemustele ning seejuures ka oma tegevusele, et vältida varasemaid eksimusi.

Kõnealune mudel võimaldab välja tuua õpetamistegevuseks vajalikud teadmised ja oskused ning neil rajanevad tegevused nii lühiajalise (üksiktunni) kui ka pikaajalise (ainekursuse) õppetöö jaoks. Kuna praktikas järgneb pärast õpilaste õpi- ja kasvatustulemustele hinnangute andmist omakorda uute eesmärkide püstitamine või mõnelgi juhul hoopis vanade korrigeerimine, vaadeldakse kõnealuses mudelis õpetamistegevust tsüklilise protsessina (Gage \& Berliner, 1998).

\section{Õppetöö planeerimise käsitlemine õpetaja praktilise teadmisena}

Õppetöö planeerimist aitab veelgi detailsemalt mõista lähtumine õpetaja praktilise teadmise kontseptsioonist. Õpetaja praktiline teadmine kui mõiste ja selle uurimine aitavad esile tuua õpetamiseks vajalikku teadmisbaasi ning see kontseptsioon on omakorda oluline täiendus olemasolevatele õpetamisteooriatele (Meijer, Verloop, \& Beijaard, 1999). Nii aitab õpetaja praktilise teadmise käsitus avada paremini õpetajate kutseteadmiste ja -oskuste olemust ning õppetöö planeerimise uurimisel näha sügavamalt õpetaja kogu teadmisbaasi, mis rakendub planeerimistegevusse.

Kuna õpetaja praktilist teadmist on uuritud erinevatest vaatenurkadest ja erinevatelt lähtealustelt, antakse järgnevalt ülevaade sellest, kuidas uurijad on seda mõistet vaadelnud, et jõuda käesoleva uurimuse jaoks sobivaima käsitluseni.

Fenstermacher (1994, viidatud Schepens, Aelterman, \& van Keer, 2007 j) eristab varasemate õpetamisalaste uurimuste põhjal kahte tüüpi õpetaja teadmist: formaalset ja praktilist. Esimene neist tuleneb õpetamisalastest uurimustest ja on teadmine õpetajate jaoks (knowledge for teachers), teine teadmine on aga loodud ja kasutatud õpetajate endi poolt (knowledge of teachers). Fenstermacher määratleb praktilist teadmist kui teadmist, mida õpetajad ise loovad oma õpetajatöö kogemuse tulemusena ja mille abil nad reflekteerivad neidsamu kogemusi.

Viimastel aastakümnetel on õpetamisalased uurimused keskendunud üha enam õpetajate tunnetusprotsessidele, mis on aluseks õpetaja käitumisele 
klassis (Carter, 1990; Meijer, Verloop, \& Beijaard, 2002). See nihe on tingitud kognitiivse psühholoogia arengust. Lähtutakse eeldusest, et inimese tunnetusprotsessid ja tegevused mõjutavad üksteist, nii nagu on vastastikuses mõjus õpetajate tunnetusprotsessid ning käitumine klassiruumis. Et mõista õpetamist, ei saa piirduda vaid õpetaja välise käitumise uurimisega, vaid arvestada tuleb ka õpetaja arutlusega, mis on selle käitumise aluseks.

Carteri (1990) järgi viitab praktiline teadmine õpetajate laialdasele teadmisele klassisituatsioonidest ja praktilistest dilemmadest, millega nad puutuvad kokku eesmärgistatud tegevuse erinevates olukordades. See teadmine kujuneb õpetaja kui professionaali isiklike kogemuste kaudu, mis hõlmavad kumulatiivselt kavatsusi, eesmärke ja ka elukogemust. Seega on praktiline teadmine tihedalt seotud praktiku eripäraga ning selles väljendub õpetaja isiklik üksikasjalik teadmine praktilistest asjaoludest, millega ta töö käigus kokku puutub.

Tingituna mõiste praktiline teadmine erinevatest käsitustest ja nendes orienteerumise vajadusest, on Meijer oma kolleegidega (1999) teinud valdkondlike uurimuste metaanalüüsi ning toonud välja erinevate käsituste ühisjooned. Nende kohaselt on praktiline teadmine a) personaalne, mis tähendab, et iga õpetaja teadmine on mingis ulatuses unikaalne; b) kontekstipõhine, mis tähendab, et see on määratletav ja kohandatav konkreetsetele klassioludele; c) kogemusel põhinev, viidates sellele, et see pärineb õpetamiskogemusest ja ka areneb läbi selle; d) õpetamistegevust suunav; e) peamiselt vaikiv, mis viitab sellele, et õpetajad ei suuda sageli seda teadmist sõnastada; ning f) ainepõhine, mis osutab seotusele õpetatava ainega. Loetletud aspekte arvesse võttes defineerivad Meijer ja tema kolleegid õpetaja praktilise teadmise teadmisena, mis hõlmab õpetaja käitumise aluseks olevaid teadmisi ja uskumusi, mis on personaalne, seotud nii aine kui ka kontekstiga, sageli vaikiv ja kogemusel põhinev.

Õpetaja praktiline teadmine koosneb ühelt poolt teadmistest ja tõekspidamistest ning teisalt interaktiivsetest tunnetusprotsessidest (Meijer et al., 2002). Teadmised ja tõekspidamised moodustavad omamoodi raamistiku, mille abil tajutakse praktikat (reflection-on-action), ning interaktiivsed tunnetusprotsessid osutavad õpetaja mõtetele õpetamise ajal (reflection-inaction). Seega on interaktiivsed tunnetusprotsessid seotud õpetaja reaalse käitumisega ehk teisisõnu, need ühitavad õpetaja teadmised ja tõekspidamised tema tegudega (Schepens et al., 2007).

Toetudes eeltoodud praktilise teadmise ühisjoontele, käsitletakse siinses artiklis Meijeri jt (1999) eeskujul praktilist teadmist kui õpetaja käitumise aluseks olevaid teadmisi ja uskumusi, mis on personaalsed, kontekstil ja kogemusel põhinevad ning sageli vaikivad. 
Õppetöö põhietappides - planeerimisel, realiseerimisel ja hindamisel/ reflekteerimisel - kasutab õpetaja aga praktilist teadmist erinevalt. Õpetamise planeerimise ja reflekteerimise etapis on kesksel kohal õpetaja varasemad teadmised, üldistused ja uskumused õpetamisest ning need pärinevad teoreetilistest ja praktilistest õpingutest. Kavandatu realiseerimise etapis domineerivad aga interaktiivsed tunnetustegevused, mis nõuavad koheste otsuste langetamise oskust (Krull \& Raudsepp, 2010).

Õpetaja praktilist teadmist aitab sügavamalt avada arusaamine õpetaja refleksiooni iseärasustest ning lühi- ja pikaajalise mälu talitlusest. Nii võimaldab mäluprotsesside mõistmine esile tuua, kuidas õpetaja kasutab oma praktilist teadmist erinevates õppetöö etappides (ehk kuidas seostuvad tema teadmised tegudega) ning millised on tema otsuste iseärasused neis etappides.

Õpetaja praktiline teadmine refleksiooni protsessis. Schöni (1983) järgi saab õpetaja kutsetegevuses eristada tegevusjärgset reflekteerimist (reflection-onaction) ja tegevusaegset reflekteerimist (reflection-in-action). Esimene neist viitab protsessile, milles õpetaja püüab mõtestada toimunud tegevust ning sellest kogemusest ka midagi õppida, mis omakorda suurendab tema teadmisbaasi. Teine refleksiooni tüüp viitab õpetaja mõtlemisele, mis ilmneb tema erinevate tegevuste käigus ja mida tüüpiliselt ei osata verbaalselt kirjeldada.

Kuid praktikas ei olegi nii kerge neid kahte refleksiooni tüüpi eristada, sest need võivad ilmneda ka samal ajal. Seetõttu arendas Eraut (1995) Schöni käsitlust edasi, tuues sisse kolmanda mõtlemise liigina eesmärgi saavutamisele suunatud refleksiooni (reflection-for-action). Selle refleksiooni avalduseks on järgneva tegevusega seostuvad ootused ja eesmärgid. Eraut' edasiarendus hõlmab ka teiste refleksiooni tüüpide täpsustusi, mille kohaselt tegevusaegne reflekteerimine (in) viitab kontekstile ning tegevusjärgne reflekteerimine (on) arutuse fookusele.

Näiteks võib õpetaja õppetöö realiseerimise etapis olenevalt kontekstist reflekteerida (in), kuidas konkreetne õppeülesanne töötab, kuidas häälestada õpilasi tõhusamalt tööle, et klassis oleks töine õhkkond, millised on alternatiivid, kui esialgu välja valitud õppemeetod ei toimi. Pärast õppetöö läbiviimist on õpetaja mõtlemine tegevuse reflekteerimisel (on) keskendunud ühele või teisele õpetamisel ilmnenud probleemile. Selles faasis hindab õpetaja, kuidas ta tegevuse sooritas, kas ta täitis seatud eesmärgi, mida ta teeks järgmisel korral teisiti jms. See refleksiooni tüüp on tihedalt seotud õpetaja eesmärgi saavutamisele suunatud refleksiooniga (for), mida õpetaja kasutab näiteks õppetööd planeerides eesmärkide määratlemisel ja õpilaste taustaga arvestamisel. Kui eesmärgi saavutamisele suunatud refleksiooni avaldusena 
määratletakse järgnevaks tegevuseks eesmärgid, siis tegelikult tulenebki selle sisend tegevuse reflekteerimisest.

Seega on õpetaja reflekteerimine protsess, mis hõlmab õpetamiseelset, -aegset ja -järgset reflekteerimist (Husu, Toom, \& Patrikainen, 2008). Õpetaja reflekteerimist võib pidada justkui protsessiks, mille käigus õpetaja oma teadmisi pidevalt ümber ehitab ning mis loob eeldused eduka õppetöö läbiviimiseks.

Õpetaja praktiline teadmine lühi- ja pikaajalise mälu protsessidena. Õpetaja praktilise teadmise mitmetahulisust (teadmised ja tõekspidamised ühelt poolt, interaktiivsed tunnetustegevused teisalt) aitab paremini mõista arusaam mälust, täpsemalt lühi- ja pikaajalisest mälust (Meijer et al., 2002). Selle kohaselt salvestuvad õpetaja teadmised ja tõekspidamised pikaajalises mälus ning interaktiivsed tunnetusprotsessid seostuvad pigem lühiajalise ehk töötava mälu tegevusega. Erinevad õpetamissituatsioonid võivad aktiveerida pikaajalisse mällu salvestunud teadmisi, mis seejärel aktiveeruvad ajutiselt ka lühiajalises mälus, olles aluseks õpetaja vahetule tegevusele.

Tunnetusprotsessina tugineb kontekstipõhine refleksioon (in) lühiajalisele mälule, sest õpetamistegevuse käigus (realiseerimisetapis) kerkivad kiiruga esile konkreetsed teadmised, kuidas midagi teha. Berlineri (1994) käsitluse järgi kasutab meisterõpetaja selles faasis korduvate tegevuste jaoks välja kujunenud automatisme, mis aitavad tal eesmärke saavutada ning võimaldavad töötaval ehk lühiajalisel mälul tegeleda pigem keerulisemate olukordadega.

Fookustatud arutlusega seostuv refleksioon (on) tugineb valdavalt pikaajalisele mälule, mille abil püüab õpetaja toimunud tegevust mõista (reflekteerimisetapp) ja uut teadmist konstrueerida. Siin arutleb õpetaja näiteks selle üle, kuidas kavandatu sai teostatud, mis onnnestus tunnis hästi, mis vajas käigu pealt modifitseerimist ning mis oli nende muudatuste põhjus. Eesmärgi saavutamisele suunatud refleksioon (for) põhineb aga nii lühi- kui ka pikaajalisel mälul, sest eesmärkide püstitamisel (planeerimisetapp) tugineb õpetaja nii varasematele teadmistele ja uskumustele kui ka hetkelisele kontekstipõhisele teadmisele. Teisisõnu, tunni õnnestumise või ebaõnnestumise põhjal teeb õpetaja järeldused tulevikuks - kuidas edaspidi konkreetset tundi või teemat planeerida, et seniseid võimalikke ebaõnnestumisi minimeerida ning tunnis püstitatud eesmärgid saavutada.

Kokkuvõtteks võib öelda, et õpetaja praktiline teadmine kui kontseptsioon pakub mitmeid lisavõimalusi õpetajate õppetöö planeerimise oskuste detailsemaks uurimiseks. 


\section{Gage'i ja Berlineri mudelis kajastuvad teadmisvaldkonnad praktilise ja teoreetilise teadmisena õppetöö planeerimisel}

Järgnevalt analüüsitakse võimalusi Gage’i ja Berlineri mudelis (1998) kajastuva formaalse teadmise ja õppetöö kolmeetapilises mudelis väljenduva praktilise teadmise kombineerimiseks tunni planeerimisel. Eesmärk on anda detailne ülevaade õppetöö planeerimise protsessist ja selle komponentidest. Ühelt poolt võimaldab Gage’i ja Berlineri mudel kirjeldada ja süstematiseerida erinevaid teadmisvaldkondi, mida on õpetajal õppetöö planeerimiseks vaja, teisalt saab õpetaja praktilise teadmise kolmeetapilise käsitluse kaudu anda Gage’i ja Berlineri mudelis esitatud õpetamisülesannete sooritamiseks vajalikele teadmistele ja oskustele praktilisema sisu, juhtides samas tähelepanu õpetajatöö põhietappide seotusele. Gage’i ja Berlineri mudeli teadmisvaldkonnad koos õppetöö kolmefaasilises mudelis kajastatava praktilise teadmisega on õppetöö planeerimise märksõnadena koondatud lisas esitatud tabelisse.

Eesmärkide määratlemine. Õpetaja varasemad teadmised, üldistused ja uskumused pärinevad nii teoreetilistest kui ka praktilistest ópingutest. Oma töö planeerimisel vajab õpetaja esmalt oskust formuleerida õppetöö eesmärgid, nagu see kajastub ka Gage’i ja Berlineri mudelis (1998). Eesmärkide püstitamisel aitavad õpetajat normatiivsed dokumendid, näiteks põhikooli ja gümnaasiumi riiklik õppekava (2011), ainekavad, kooli kodukord, aga ka üldine oskus eesmärke sõnastada. Praktilise teadmise käsituse järgi on eesmärkide püstitamisel abiks ka õpetaja enda varasem kogemus ja arusaam sellest, kuidas tuleks õpilasi kasvatada täisväärtuslikeks kodanikeks, kuidas olla ise eeskujuks, kuidas suunata ja juhtida klassi, ning teadmine oma klassi eripärast milleks on tema õpilased võimelised.

Planeerimisel püstitatud eesmärkidest saab õpetaja lähtuda realiseerimisetapis. Selles etapis võib aga esineda erinevaid stsenaariume, näiteks kas püstitatud eesmärgid täidetakse või jäävad need mingisugusel põhjusel kas osaliselt või täielikult täitmata. Ent meisterõpetaja ennetab ebaõnnestumisi, mõeldes juba planeerimisetapis erinevatele alternatiivsetele lahenduskäikudele, kui kavandatu ei peaks tunnis realiseeruma plaanipäraselt. Meisterõpetaja teab oma kogemusest, et õpetamine nõuab oludele kohandumist, ning seetõttu mõtleb ta alternatiivsetele võimalustele juba õppetöö planeerimisel. Realiseerimisetapis kogetu ja selle reflekteerimine on õpetajale omakorda tagasisideks, millega ta paratamatult arvestab oma edasise tegevuse kavandamisel.

Õpilaste/klassi eripära arvestamine. Järgmine teadmisvaldkond, mis aitab ópetajat planeerimisel, on arusaam oma õpilastest. See tähendab, et siinkohal on õpetajale abiks teadmised arengupsühholoogiast (Krull, 2000), näiteks 
millised on tema õpilased vaimsetelt võimetelt ja millises arenguetapis nad on. Vähem olulised ei ole teadmised õpilase sotsiaalsest, kõlbelisest ning ka füüsilisest arengust. Peale õpilaste individuaalse arengutaseme tuleb õpetajal arvestada ka klassi kui rühma käitumisega.

Varasema kogemuse baasil on õpetajal praktilise teadmise näol ettekujutus sellest, kes on tema õpilased (nii individuaalsel kui ka rühma tasandil): milleks on nad võimelised, milliseid eesmärke tuleks õpilasi arvestades püstitada, kuidas õpetaja arvestab õpilaste ainealaseid teadmisi ja oskusi, millist materjali on nendega reaalne käsitleda jne. Sedalaadi vahetut infot saab õpetaja eelkõige eelmiste tundide põhjal. Samuti on õpilaste eripära arvestamisel tähtsal kohal õpetaja enda hoiakud õpilaste suhtes.

Kuna õppetöö käiku ei saa täielikult ette näha, mõtleb õpetaja planeerimisetapis ka sellele, millised võiksid olla erinevad alternatiivid juhtudeks, kui tunnis kerkivad esile ettenägematud olukorrad või esialgu planeeritu ei realiseeru ootuste kohaselt. Oma õpilaste käitumine on õpetajale üldjuhul ootuspärane, kuid vahel võib ette tulla selliseid olukordi, kus see lööb õpetaja plaanid segamini (nt erilised sündmused koolis, veerandi viimane tund, liiga raskeks osutunud õppeülesanne). Selliseid olukordi ettenägevana on kogenud õpetaja planeerimisetapis paindlik ning ta püüab leida erinevaid võimalusi, mis võiksid õpilastele tavapärastest valikutest sobilikumaks osutuda.

See, kuivõrd õnnestus õpetajal realiseerimisetapis õpilaste/klassi eripäraga arvestada, mõjutab tema mõtteid ja otsuseid hindamisetapis ning tema edasist tegevust. Seetõttu annab realiseerimis- ja hindamisetapis saadud kogemus õpetajale vahetut tagasisidet, kuidas oma tööd edaspidi planeerida.

Õppimise ja motivatsiooni mõistmine ning saadud teadmiste rakendamine. Kolmas oluline aspekt, millega õpetajal tuleks õppetöö planeerimisel arvestada, on õppimise ja motiveerimisega seotud teadmiste teadvustamine. Motivatsiooni ja soodsa klassiõhkkonna kujundamine on pikaajaline protsess klassi ja õpetaja vahel kujunevas suhtes, mida ei ole võimalik saavutada mingi ühekordse tegevuse tulemusel.

Ôppimise ja motiveerimise puhul aitab õpetajat teoreetiline teadmine sellest, kuidas kujundada klassis soodne õpikeskkond. Positiivse õpiorientatsiooni tekkimist võimaldab paremini lahti mõtestada Ames’i mudel (1992), mille kohaselt kujundavad õpikeskkonda õppeülesanded, kasutatav hindamissüsteem ning õppimise eest vastutuse jaotus klassis. Et mõista õpilase õppimisvõimalusi, tuleks Ames’i kohaselt süüvida eelkõige psühholoogilisse keskkonda, milles õpilane elab. See aitab õpetajal mõista õpilase kujutlusi, tajusid ja emotsioone seoses vahetute ülesannetega ning seeläbi ka ülesannete lahendamiseks tehtavate jõupingutuste iseloomu. 
Soodsa õpikeskkonna loomisel on õpetajale abiks ka teoreetiline teadmine distsipliinist ja selle alalhoidmisest. Distsipliini saavutamist mõjutavad õpetaja enda isikuomadused, tema sobivus erinevas vanuses õpilastega, tema roll sotsialiseerija ja kasvatajana ning ka tema juhtimisstiil (Krull, 2000).

Distsipliini alalhoidmist töös klassiga aitavad sügavamini mõista Weinsteini ja Mignano (1993) uurimused, mis näitasid, et heade õpetajate edu klassiga toimetulekul ilmneb pigem oskusest probleeme ennetada, kui neid pärast ilmnemist kõrvaldada. Seega peitub õpetajate edu klassi ohjamisel suuresti selles, milliseid meetodeid nad kasutavad korrarikkumiste ärahoidmiseks, st et distsipliin põhinebki kogu õppetöö edukal korraldusel. Kounini (1970) uurimuste põhjal on teada, et klassis tagab distsipliini tegevuse hoogsus. See saavutatakse, kui õpetaja järgib klassiga töötades kindlaid põhimõtteid hälbiva käitumise ennetamisel, tunni edenemisel ja tempo suunamisel, samuti peab ta hoolitsema selle eest, et õpilased keskenduksid tööle.

Kounini (1970) kohaselt aitavad hälbivat käitumist tunnis ennetada õpetaja kohalolek ning üheaegsed ehk kattuvad tegevused. Esimene neist tähendab seda, et õpetaja on teadlik klassis toimuvast ja suuteline toimuvat jälgima. Üheaegsete ehk kattuvate tegevuste all peab Kounin silmas õpetaja oskust aidata näiteks abi vajavat õpilast, ilma et tal sellega jääks tähelepanuta ülejäänud klassi tegevus. Teine oluline põhimõte, mis lihtsustab korra tagamist, on sobiva tunni tempo hoidmine ning ühelt tegevuselt teisele sujuv üleminek. Kolmandaks peab õpetaja tegevuse hoogsuse ja õpilaste tähelepanu säilitamiseks tagama õpilaste aruandluskohustuse ja kaasatöötamise. Klassi püsiva tähelepanu saavutamine nõuab õpetajalt oskust õpilasi küsitleda, nii et kõik õpilased on pidevalt vastamiseks valmis, ning õpilaste aruandluskohustus tähendab seda, et õpilased teadvustavad oma vastutust õppimise ees, on valmis adekvaatselt reageerima õpetaja nõuetele ja näitavad oma käitumisega, et tund läheb neile korda.

Õppimise, motiveerimise ja soodsa õpikeskkonna kujundamiseks vajalike meetmete kavandamisel tugineb õpetaja oma praktilise teadmise abil varasematele teadmistele ja kogemustele sellest, kuidas häälestada klassi õppima ja motiveerida seejuures ka üksikõpilast. Lisaks arvestab õpetaja, millised on tema võtted ühe või teise olukorra saavutamiseks, mis on varem hästi töötanud ning mis nii edukaks ei ole osutunud. Töise õpikeskkonna tagamisel on olulisel kohal see, kuidas õpetaja kehtestab oma töökorra ja kokkulepped ning kui järjekindel on ta ise nende järgimisel.

Õpetaja võib küll õppetöö planeerimisel arvestada sellega, kuidas hoida õpilasi motiveerituna ja panna neid tööle, kuid praktikas võib juhtuda, et ta ei suuda tunnis korda tagada, mistõttu võib tekkida probleeme distsipliiniga. See ei olene õpetaja kogemusest või pingutusest, sest paljud olukorrad on 
õpetajale ettearvamatud ja tema poolt kontrollimatud. Et reaalses tunnis sellist olukorda vältida, mõtleb õpetaja juba planeerimisel erinevate võimaluste peale, kuidas klassi häälestada õppimisele ja hoida õpilaste tähelepanu õppetööl. Arusaamine tunnist kui interaktsioone täis protsessist, mis ei ole õpetaja jaoks pisiasjadeni etteaimatav, on üks põhjusi, miks õpetajad ei koosta detailseid tunnikonspekte, vaid pigem tajuvad intuitiivselt, mis on õige ja milliseid alternatiivseid lahendusi saab kasutada. Ühe konkreetse tunni kordaminek mõjutab õpetaja edaspidist vahetut planeerimistegevust.

Õppemeetodite väljavalimine ja rakendamine. Õppetöö eesmärkide saavutamiseks on oluline valida sobivad õppemeetodid ja neid rakendada. Uue materjali edastamiseks ja erinevate õpilastega töötamiseks on palju võimalusi, mis võivad ulatuda õpitava loengulisest esitamisest kuni iseseisva uurimistegevuseni. Õppemeetodi valiku võimalustes orienteerumiseks saab toetuda Gagné õppeühiku mudelile (Gagné \& Driscoll, 1992), mis toob esile tunni põhisündmused. Need on järgnevalt esitatud kõige tõenäolisemas esinemise järjekorras: a) õpilaste tähelepanu haaramine, b) õppetunni eesmärkidest informeerimine ja õpilaste motiveerimine, c) varem õpitu meeldetuletamine, d) uue materjali esitamine/õppimine, e) õppimise suunamine, f) õpitu kontrollimine, g) õpitu kohta tagasiside tagamine, h) õppimisele hinnangu andmine ning i) õpitu kinnistamine ja üldistamine.

Võimalusi, milliseid metoodilisi võtteid õpetaja tundi planeerides erinevateks etappideks valib, on palju. Näiteks ei pruugi meisterõpetaja tunni alguses õpilaste tähelepanu haaramiseks ühtegi võtet kasutada, sest õpilased kuulavad teda niisamagi ning asuvad kohe tööle. Ent algaja õpetaja võib mõelda planeerimisel erinevatele võimalustele, kuidas suunata õpilaste tähelepanu õppimisele (nt ootamatu üllatus, tavapärasest erinev hääletoon). Samamoodi on mitmeid võimalusi, kuidas õpilasi õppetöö eesmärkidest teavitada ja neid motiveerida (nt kasulikkus edaspidises elus). Ka uue osa õppimise toetamisel on õpetajal võimalik esitada küsimusi või lisada õppeülesannetele vastavad juhised, mis aitavad õpilastel mõista õpitava olulisust. Need on siinkohal vaid mõned üksikud näited metoodilistest võtetest, mida õpetaja saab tunni erinevateks etappideks valida.

Sobivate meetodite või metoodiliste võtete väljavalimisel tugineb õpetaja oma praktilisest teadmisest tulenevale kogemusele, milline meetod on konkreetse teema puhul osutunud varem sobivaks. Veelgi enam aitab õpetajat õpilaste tundmine: kes on tema õpilased, mis võiks neile huvi pakkuda, millisel õppeastmel nad õpivad, milline on nende tase jne. Ent uudses olukorras või uute õpilastega töötades võib juhtuda, et õpetaja rakendab katse ja eksituse põhimõtet, mõistmaks, milline meetod võiks õpilastele selle teema puhul 
sobida. Samuti võib juhtuda, et esialgu väljavalitud meetod osutub ebatõhusaks, mistõttu tuleb õpetajal seda tunni käigus kohandada, et õppimine oleks võimalikult tõhus. Selline katsetamine (sh õppemeetodite modifitseerimine) on õpetajatöös loomulik, sest ühe või teise õppemeetodi rakendamise edukus ja sobivus olenevad nii õpetaja kui ka klassi eripärast.

Kuigi õpetaja modifitseerib mõnda meetodit vahetult õpetamise käigus, on ta võimalikud alternatiivid juba õppetööd planeerides läbi mõelnud. Nii on ta realiseerimisetapis ootamatusteks valmis ja suudab reageerida viisil, mis häirib õpilaste õppimist minimaalselt. Nii nagu eelmiste teadmisvaldkondade puhul, kandub ka siin õpetaja analüüsist tulenev kogemus õppemeetodite töökindlusest edasi tema edaspidisesse planeerimisse.

Õpitulemuste hindamine. Õpetamistsükli viimane tegevusetapp hõlmab õpetaja tegevust pärast õpetamist ning siinkohal on keskseks tegevuseks õpitulemuste hindamine. Õpitulemuste hindamine eeldab õpetajalt üsnagi mitmele aspektile mõtlemist ja seda juba planeerimisetapis. Näiteks peab ta otsustama, milliste vahendite abil ta õpitulemusi kontrollib, milliseid meetodeid hindamisel rakendab ja mis liiki hindamist kasutab. Paralleelselt õpitulemustega hindab õpetaja siin etapis ka oma tehtud tööd ning teeb selle põhjal järeldused edaspidiseks tegevuseks.

Oma igapäevatöös rakendab õpetaja nii formaalset kui ka mitteformaalset hindamist. Mitteformaalsel hindamisel kasutab õpetaja oma kogemuslikke muljeid klassi arengutaseme ja õpilaste vastamise üle otsustamiseks. Põhiliselt hõlmab see kolme valdkonda: a) õpilaste ja klassi üldise arengutaseme, õpimotivatsiooni ja distsiplineerituse hindamist, b) klassi kaasatöötamisvõime jälgimist õpetamise käigus ja c) õpilaste jooksvat hindamist tunnis (Airasian, 1994). Mitteformaalne hindamine on aga üsna subjektiivne. Formaalse hindamise puhul on hindamisprotseduur rangemalt määratletud ja tulemused vormistatakse kirjalikult. Sellist hindamist rakendatakse nii jooksvate õpitulemuste kui ka pikemaajalise õppimise tulemuste väljaselgitamiseks.

Selleks, et õpitulemusi hinnata, peab õpetaja läbi mõtlema eelkõige selle, milliseid kontrollvahendeid ta kasutab. Kontrollvahendid võivad olla väga erinevad, näiteks sooritustestid (õpitulemuste kontrollimine vahetu soorituse põhjal), essee tüüpi küsimused, õpilaste õpimapid ning valik- ja lühivastuselised testiküsimused (Airasian, 1994).

Oma praktilisele teadmisele toetudes langetab õpetaja õpitulemuste hindamisel otsused, kuivõrd edukalt on õpilased materjali omandanud. Õpetaja analüüsib, millised on klassi üldised õpitulemused, kas käsitletud teemat peaks veel kordama ja selgitama või on õpitulemused piisavad, et liikuda edasi uue osaga. Siinkohal tuleks õpetajal hinnata ka oma tööd. Kui õpetajale ei ole 
hindamise tulemused ootuspärased, peaks ta analüüsima seda, mis võis osutuda õpilastele üle jõu käivaks. Õpetaja peab endale teadvustama, et õpituga tuleks veel tegeleda, alles seejärel saab uue osaga edasi minna. Tehtud järelduste põhjal korrigeerib õpetaja oma edasist tööd. Järelduste tegemine ei pruugi aga alati kerge olla, sest refleksioon nõuab õpetajalt enda vastu ausaks jäämist. Kuna õpetaja reflekteerimine on lõputu protsess, siis peaksid õpetajad nägema selles tööriista, mis aitab neil oma ametis pidevalt areneda ja õppida.

Seega eeldab õpitulemuste hindamine õpetajalt oskust selgusele jõuda nii õpilaste jõupingutustes kui ka enda tehtud töös. Õpitulemuste hindamisel toetub õpetaja sellele, kuivõrd kooskõlas oli planeeritu ja realiseeritu. Kogetu põhjal teeb ta vajalikud korrektuurid edaspidise töö planeerimisel.

\section{Küsimustik õpetajate õppetöö planeerimise oskuste uurimiseks}

Eelmises alajaotises keskenduti õppetöö planeerimisele kui protsessile, mis on Gage'i ja Berlineri mudeli (1998) üks põhikomponente. Seejuures arvestati planeerimistegevust mõjutavate ettearvatavate probleemidega õppetöö läbiviimisel ja varasema kogemuse reflekteerimise mõjuga. Nii valmis tabelikujuline mudel (vt tabel 1), mis kujutab planeerimisel käivituvat arutelu kolmel tasemel. Tabeli vertikaaltelje moodustavad Gage'i ja Berlineri mudeli õpetamisülesanded ja horisontaaltelje õppetöö põhietapid. Vahetu planeerimise tasandil vaadeldakse mõtlemisprotsesse õppetöö läbiviimise ja reflekteerimise etapist saadud tagasisidet rõhutamata (planeerimine siin ja praegu). Planeerimine õppetöö läbiviimisest tuleneva tagasisidega (planeerimine mõeldes realiseerimisele) kajastab õpetaja mõtteid, mis tal planeerimisel tekivad, keskendudes eelseisvas tunnis või õppetöös etteaimatavale interaktsioonile klassiga. See-eest planeerimine mõeldes varasemast kogemusest tehtud järeldustele (planeerimine mõeldes reflekteerimisele) osutab õpetaja mõtetele, mis tal tekivad reflekteerimisest pärit arutluste põhjal. Loodud mudel võimaldab Gage'i ja Berlineri mudeli põhikomponentidega seostatuna esitada planeerimistegevuse uurimiseks küsimusi kolmel tasandil: a) küsimused lihtsalt tunni või kursuse planeerimise kohta, ilma et rõhutataks tagasisidet interaktsioonilisest (realiseerimis-) või hindamisetapist; b) küsimused planeerimistegevuse kohta, rõhutades eelseisva õppetöö võimalikku mõju planeerimisele, ning c) küsimused selle kohta, kuidas eelneva tegevuse reflekteerimine mõjutab planeerimist.

Kirjeldatud mudeli põhjal koostati küsimustik õppetöö planeerimise oskuste uurimiseks. See koosneb viiest suuremast teemavaldkonnast, mis tulenevad Gage'i ja Berlineri esitatud mudelist (1998). Need on a) eesmärkide 
määratlemine, b) õpilaste/klassi eripära arvestamine, c) õppimise ja motivatsiooni mõistmine ning saadud teadmiste rakendamine, d) õppemeetodite väljavalimine ja rakendamine ning e) õpitulemuste hindamine. Iga teemavaldkonna küsimused on seostatud kolme õppetööetapiga - planeerimise, realiseerimise, hindamise/reflekteerimisega -, mis tuleneb eelnevas analüüsis välja toodud vajadusest.

Tabel 1. Õppetöö planeerimisel avalduvate mõtlemisprotsesside kirjelduse mudel kolme õppetööetapi kaupa ning Gage'i ja Berlineri (1998) mudeli alusel (nooled tähistavad sisendit planeerimisetappi)

\begin{tabular}{l|c|c|c}
\hline \multicolumn{1}{c|}{ PLANEERIMINE } & $\begin{array}{c}\text { Planeerimine } \\
\text { (planeerimine } \\
\text { siin ja praegu) }\end{array}$ & $\begin{array}{c}\text { Realiseerimine } \\
\text { (planeerimine } \\
\text { mõeldes } \\
\text { realiseerimisele) }\end{array}$ & $\begin{array}{c}\text { Hindamine/reflek- } \\
\text { teerimine } \\
\text { (planeerimine } \\
\text { mõeldes } \\
\text { reflekteerimisele) }\end{array}$ \\
\hline Eesmärgid & $\mathrm{X}$ & $\leftarrow \mathrm{x}$ & $\leftarrow \mathrm{x}$ \\
\hline Õpilaste/klassi eripärad & $\mathrm{X}$ & $\leftarrow \mathrm{x}$ & $\leftarrow \mathrm{x}$ \\
\hline Õppimine ja motivatsioon & $\mathrm{X}$ & $\leftarrow \mathrm{x}$ & $\leftarrow \mathrm{x}$ \\
\hline Õppemeetodid & $\mathrm{X}$ & $\leftarrow \mathrm{x}$ & $\leftarrow \mathrm{x}$ \\
\hline Hindamine/reflekteerimine & & $\leftarrow \mathrm{x}$ & \\
\hline
\end{tabular}

Toetudes eespool kirjeldatud mudelile, vaadeldakse vahetu planeerimise puhul Gage’i ja Berlineri mudeli komponente teiste etappidega vähe seostatult, see tähendab, et küsimused on sõnastatud nii, et need ei kutsu otseselt mõtlema eelseisvale interaktsioonile ja reflekteerimisele. Realiseerimisetapi positsioonilt on küsimused püstitatud suunitlusega ette aimata, kuidas aimus tunnis juhtuvast mõjutab planeerimistegevust ning millist mõju avaldab vahetu, tunnijärgne reflekteerimine edasisele planeerimisele. Küsimustega reflekteerimisetapi kohta püütakse hinnata, kuidas mõjutab kogetu rahulik ja tasakaalukas reflekteerimine õppetöö edasist planeerimist. Seega on iga teemavaldkonna avamiseks kasutatud küsimusi vahetu planeerimise kohta ning realiseerimisetapist ja reflekteerimis- ehk hindamisetapist saadud tagasisidet.

Terves küsimustikus on iga teemavaldkonna küsimuste esitamisel järgitud ühesugust mustrit. See tähendab, et küsimused käsitlevad nii kolme õppetööetappi kui ka planeerimistoimingute lähtumist lühi- (tunni) ja pikaajalisest (ainekursuse) planeerimisest. Küsimustiku struktuurist annab ülevaate tabel 2 , kus detailsemalt on välja toodud iga teemavaldkonna küsimuste püstitamise põhimõtted õppetöö eesmärkide püstitamise valdkonna näitel. 
Tabel 2. Õppetöö planeerimise oskusi kajastava küsimustiku ülesehitus (detailselt on avatud eesmärgistamise teadmisvaldkond, teiste valdkondade puhul on järgitud analoogset mustrit)

\begin{tabular}{|c|c|c|}
\hline \multicolumn{3}{|l|}{ I Taustaandmed } \\
\hline \multicolumn{3}{|l|}{ II Õppetöö planeerimine } \\
\hline \multicolumn{3}{|l|}{ II.I Õppetöö eesmärkide püstitamine } \\
\hline \multirow[t]{2}{*}{ Õppetöö etapp } & \multicolumn{2}{|c|}{ Planeerimise liik } \\
\hline & Tunni planeerimine & Kursuse planeerimine \\
\hline $\begin{array}{l}\text { Planeerimine ehk planeerimine siin } \\
\text { ja praegu }\end{array}$ & Näide 1 & Näide 4 \\
\hline $\begin{array}{l}\text { Realiseerimine ehk planeerimine } \\
\text { mõeldes realiseerimisele }\end{array}$ & Näide 2 & Näide 5 \\
\hline $\begin{array}{l}\text { Hindamine/reflekteerimine ehk pla- } \\
\text { neerimine mõeldes reflekteerimisele }\end{array}$ & Näide 3 & Näide 6 \\
\hline \multicolumn{3}{|l|}{ II.II Õpilaste/klassi eripära arvestamine } \\
\hline \multicolumn{3}{|c|}{ II.III Õppimise ja motivatsiooni mõistmine ning saadud teadmiste rakendamine } \\
\hline \multicolumn{3}{|c|}{ IIIIV Õppemeetodite väljavalimine ja rakendamine } \\
\hline II.V Õpitulemuste hindamine & & \\
\hline
\end{tabular}

Järgnevalt on esitatud tabeli 2 näited küsimuste püstitamise põhimõtetest eesmärgistamise valdkonna eeskujul.

Näide 1. Eesmärgistamine eelseisva tunni planeerimisel

Kui kavandate eelseisvat tundi, siis millist alltoodud eesmärki näete oma töös kõige olulisemana? Vastamiseks tehke rist vastavasse lahtrisse.

\begin{tabular}{l|l|l|l|l|l}
\hline Eesmärk & $\begin{array}{c}\text { Üldse } \\
\text { pole } \\
\text { oluline }\end{array}$ & $\begin{array}{c}\text { Vähe- } \\
\text { oluline }\end{array}$ & $\begin{array}{c}\text { Kesk- } \\
\text { miselt } \\
\text { oluline }\end{array}$ & $\begin{array}{c}\text { Olu- } \\
\text { line }\end{array}$ & $\begin{array}{c}\text { Väga } \\
\text { oluline }\end{array}$ \\
\hline $\begin{array}{l}\text { Viia tund läbi nii, et direktsioon oleks } \\
\text { minu tööga rahul }\end{array}$ & & & & & \\
\hline $\begin{array}{l}\text { Õpetada tunniga seostuv materjal } \\
\text { selgeks }\end{array}$ & & & & & \\
\hline $\begin{array}{l}\text { Arendada õpilastes tunni jooksul } \\
\text { teemakohaseid teadmisi/oskusi }\end{array}$ & & & & & \\
\hline $\begin{array}{l}\text { Saavutada dokumentides (nt õppe- } \\
\text { kavas, ainekavas) fikseeritud eesmärgid }\end{array}$ & & & & & \\
\hline Tagada distsipliin & & & & & \\
\hline
\end{tabular}

Muu: 
Näide 2. Realiseerimisetapi mõju arvestav eesmärgistamine tunni planeerimisel Milline loetletud asjaoludest segab Teie arvates kõige rohkem tunni eesmärkide saavutamist?

\begin{tabular}{l|l|l|l|l|l}
\hline Tundi segavad asjaolud & $\begin{array}{c}\text { Üldse ei } \\
\text { sega }\end{array}$ & $\begin{array}{c}\text { Segab } \\
\text { vähe }\end{array}$ & Segab & $\begin{array}{c}\text { Segab } \\
\text { oluliselt }\end{array}$ & $\begin{array}{c}\text { Segab } \\
\text { väga } \\
\text { oluliselt }\end{array}$ \\
\hline $\begin{array}{l}\text { Ootamatud sündmused, mis häirivad } \\
\text { tundi/päeva }\end{array}$ & & & & & \\
\hline $\begin{array}{l}\text { Õpilaste järjepidev korrarikkumine } \\
\text { tunnis }\end{array}$ & & & & & \\
\hline $\begin{array}{l}\text { Tunnis toimuv õpilastevaheline suhtlus, } \\
\text { mida ei ole võimalik ette näha }\end{array}$ & & & & & \\
\hline $\begin{array}{l}\text { Tunnis õpetamiseks valitud ebasobiv } \\
\text { õppemeetod (enda ja/või õpilaste ja- } \\
\text { oks) }\end{array}$ & & & & & \\
\hline Õpilaste ainealane võimekus & & & & & \\
\hline
\end{tabular}

Muu:

Näide 3. Reflekteerimisetapi mõju arvestav eesmärgistamine tunni planeerimisel

Kui sageli leiate aega tunniks püstitatud eesmärkide täitmise ja täitmata jätmise analüüsiks kas tundide vahel või peale tunde?

\begin{tabular}{l|l|l|l|l}
\hline Mitte kunagi & Harva & Aeg-ajalt & Väga sageli & Alati \\
\hline & & & & \\
\hline
\end{tabular}

Näide 4. Eesmärgistamine kursuse planeerimisel

Kui kavandate ainekursuse õpetamist, siis millist alltoodud eesmärki näete oma töös kõige olulisemana?

\begin{tabular}{l|l|l|l|l|l}
\hline Eesmärk & $\begin{array}{c}\text { Üldse } \\
\text { pole } \\
\text { oluline }\end{array}$ & $\begin{array}{c}\text { Vähe- } \\
\text { oluline }\end{array}$ & $\begin{array}{c}\text { Kesk- } \\
\text { miselt } \\
\text { oluline }\end{array}$ & $\begin{array}{c}\text { Olu- } \\
\text { line }\end{array}$ & $\begin{array}{c}\text { Väga } \\
\text { oluline }\end{array}$ \\
\hline $\begin{array}{l}\text { Viia teemaga seostuvad tunnid läbi nii, } \\
\text { et direktsioon oleks minu tööga rahul }\end{array}$ & & & & & \\
\hline $\begin{array}{l}\text { Õpetada teemaga seostuv materjal } \\
\text { selgeks }\end{array}$ & & & & & \\
\hline $\begin{array}{l}\text { Arendada õpilastes teemakohaseid } \\
\text { teadmisi/oskusi }\end{array}$ & & & & & \\
\hline $\begin{array}{l}\text { Saavutada dokumentides (nt } \\
\text { õppekavas, ainekavas) fikseeritud } \\
\text { eesmärgid }\end{array}$ & & & & & \\
\hline Tagada püsiv distsipliin klassis & & & & & \\
\hline
\end{tabular}

Muu: 
Näide 5. Realiseerimisetapi mõju arvestav eesmärgistamine kursuse planeerimisel Milline loetletud asjaoludest segab kõige enam planeeritud eesmärkide saavutamist ainekursuse õpetamisel?

\begin{tabular}{l|l|l|l|l|l}
\hline Kursuse õpetamist segavad asjaolud & $\begin{array}{c}\text { Üldse ei } \\
\text { sega }\end{array}$ & $\begin{array}{c}\text { Segab } \\
\text { vähe }\end{array}$ & Segab & $\begin{array}{c}\text { Segab } \\
\text { oluliselt }\end{array}$ & $\begin{array}{c}\text { Segab } \\
\text { väga } \\
\text { oluliselt }\end{array}$ \\
\hline $\begin{array}{l}\text { Ootamatud sündmused, mis häirivad } \\
\text { tundi/päeva }\end{array}$ & & & & & \\
\hline $\begin{array}{l}\text { Õpilaste järjepidev korrarikkumine } \\
\text { tundides }\end{array}$ & & & & & \\
\hline $\begin{array}{l}\text { Tunnis toimuv õpilastevaheline suhtlus, } \\
\text { mida ei ole võimalik ette näha }\end{array}$ & & & & & \\
\hline $\begin{array}{l}\text { Teema õpetamiseks valitud } \\
\text { ebasobiv(ad) õppemeetod(id) (enda ja/ } \\
\text { või õpilaste jaoks) }\end{array}$ & & & & & \\
\hline Õpilaste ainealane võimekus & & & & & \\
\hline
\end{tabular}

Muu:

Näide 6. Reflekteerimisetapi mõju arvestav eesmärgistamine kursuse planeerimisel Kui sageli leiate aega ainekursuse õpetamiseks püstitatud eesmärkide täitmise ja täitmata jätmise analüüsiks?

\begin{tabular}{l|l|l|l|l}
\hline Mitte kunagi & Harva & Aeg-ajalt & Väga sageli & Alati \\
\hline & & & & \\
\hline
\end{tabular}

Realiseerimis- ja hindamisetapi küsimuste formuleerimisel tugineti Husu jt (2008) käsitusele, mille kohaselt saab õpetaja tunnetustegevuses eristada kuuma ja külma refleksiooni. Esimene neist seostub õpetaja vahetu reflekteerimisega tunnete ajel, teine aga rahumeelse reflekteerimisega hetkel, kui esmased emotsioonid on jahtunud. Selle käsitlusega toetatakse õpetaja reflekteerimise iseärasusi eelnimetatud etappides.

Koostatud küsimustik hõlmab uuritavate taustaandmete küsimusi ja 35 küsimust õppetöö planeerimise oskuse kohta. Õppetöö planeerimise oskust käsitlevad küsimused on esitatud Likert-tüüpi viiepalliliste skaaladena. Küsimusele vastamiseks tuleb uuritaval teha märge lahtrisse, mis on kõige lähem tema arvamusele. 


\section{Kokkuvõte}

Õppetöö planeerimine on keeruline protsess, mille teaduslikult usaldusväärne uurimine eeldab sellest võimalikult adekvaatse mudeli loomist. Käesolevas uurimuses esitatud mudeli puhul on tuginetud Gage’i ja Berlineri mudelile õpetamisülesannetest, mida täidetakse õpetaja praktilise teadmise toel õppetöö kavandamise, realiseerimise ja reflekteerimise etapis.

Mudeli põhjal loodi küsimustik algajate ja meisterõpetajate planeerimisoskuste uurimiseks. Küsimustik hõlmab viit õppetöö planeerimisega seotud teemavaldkonda. Nendeks on a) eesmärkide määratlemine, b) õpilaste/klassi eripära arvestamine, c) õppimise ja motivatsiooni mõistmine ning saadud teadmiste rakendamine, d) õppemeetodite väljavalimine ja rakendamine ning e) õpitulemuste hindamine.

Vastavalt loodud teoreetilisele mudelile esitatakse küsimustikus iga teemavaldkonnaga seotud küsimused kolmel tasandil: vahetu planeerimine (realiseerimis- ja hindamisetapist saadava tagasisideta), planeerimistegevus, mille puhul rõhutatakse eelseisva õppetöö etteaimatavat mõju planeerimisele, ning viimaseks kogetu reflekteerimise mõju planeerimisele. Formaalselt on õppetöö planeerimist kajastavad küsimused esitatud Likert-tüüpi viiepalliliste skaaladena.

Õppetöö planeerimist kajastava teoreetilise mudeli rakendamine küsimustiku väljatöötamisel on õppetöö planeerimise uurimisel uudne. Samas mõistavad artikli autorid, et õppetöö planeerimise modelleerimine Gage’i ja Berlineri õpetamise põhiülesannete mudeli ning õppetöö kolmeetapilise mudeli põhjal on vaid üks võimalik viis uurida õpetajate õppetöö planeerimise oskusi.

\section{Tänusõnad}

Artikli valmimist toetas Euroopa Sotsiaalfondi EDUKO projekt „Õpetajate professionaalne areng ja selle toetamine” (1.2.0302.09-004) ning haridus- ja kasvatusteaduste doktorikool (1.2.0401.09-0070).

\section{Kasutatud kirjandus}

Airasian, P. W. (1994). Classroom assessment (2nd ed.). New York: McGraw-Hill.

Ames, C. (1992). Classrooms: Goals, structures, and student motivation. Journal of Educational Psychology, 84(3), 261-271. http://dx.doi.org/10.1037/0022-0663.84.3.261

Berliner, D. C. (1994). Expertise: The wonder of exemplary performances. In J. N. Mangieri \& C. Collins Block (Eds.), Creating powerful thinking in teachers and students: Diverse perspectives (pp. 161-186). Fort Worth: Harcourt Brace.

Carter, K. (1990). Teachers' knowledge and learning to teach. In W. R. Houston, M. Haberman \& J. P. Silkula (Eds.), Handbook of research on teacher education (pp. 291-310). New York: Macmillan. 
Clark, C. M., \& Yinger, R. J. (1987). Teacher planning. In D. C. Berliner \& B. V. Rosenshine (Eds.), Talks to teachers (pp. 342-365). New York: Random House.

Darling-Hammond, L., Hammerness, K., Grossman, P., Rust, F., \& Shulman, L. (2005). The design of teacher education programs. In L. Darling-Hammond \& J. Bransford (Eds.), Preparing teachers for a changing world: What teachers should learn and be able to do (pp. 390-441). San Francisco: Jossey-Bass.

Eggen, P., \& Kauchak, D. (2013). Educational psychology: Windows on classrooms (9th ed.). Boston: Pearson.

Eraut, M. (1995). Schön shock: A case for reframing reflection-in-action? Teachers and Teaching: Theory and Practice, 1(1), 9-22.

Gage, N. L., \& Berliner, D. C. (1998). Educational psychology (6th ed.). Boston: Houghton Mifflin Co.

Gagné, R. M., \& Driscoll, M. P. (1992). Õppimise olemus ja õpetamine. Tartu: Tartu Ülikool.

Gümnaasiumi riiklik óppekava (2011). Külastatud aadressil https://www.riigiteataja.ee/ akt/114012011002.

Husu, J., Toom, A., \& Patrikainen, S. (2008). Guided reflection as a means to demonstrate and develop student teachers' reflective competencies. Reflective Practice: International and Multidisciplinary perspectives, 9(1), 37-51. http://dx.doi.org/10.1080/14623940701816642

Kansanen, P. (1981). The way thinking is: How do teachers think and decide? In E. Komulainen \& P. Kansanen (Eds.), Classroom analysis: Concepts, findings, applications. Research Bulletin, 56, 31-38. Helsinki: University of Helsinki.

Kounin, J. (1970). Discipline and group management in classrooms. New York: Holt, Rinehart \& Winston.

Krull, E. (2000). Pedagoogilise psühholoogia käsiraamat. Tartu: Tartu Ülikooli Kirjastus.

Krull, E., \& Raudsepp, I. (2010). Perspectives for optimizing the school practicum for student teachers through a study of Dutch, Estonian and Finnish experiences. In J. Mikk, M. Veisson \& P. Luik (Eds.), Teacher's personality and professionalism (pp. 141-158). Frankfurt am Main: Peter Lang Publishers House.

Meijer, P. C., Verloop, N., \& Beijaard, D. (1999). Exploring language teachers' practical knowledge about teaching reading comprehension. Teaching and Teacher Education, 15(1), 59-84. http://dx.doi.org/10.1016/S0742-051X(98)00045-6

Meijer, P. C., Verloop, N., \& Beijaard, D. (2002). Multi-method triangulation in a qualitative study on teachers' practical knowledge: An attempt to increase internal validity. Quality and Quantity, 36(2), 145-167. http://dx.doi.org/10.1023/A:1014984232147

Põhikooli riiklik õppekava (2011). Külastatud aadressil https://www.riigiteataja.ee/akt/ 120092011009.

Schepens, A., Aelterman, A., \& van Keer, H. (2007). Studying learning processes of student teachers with stimulated recall interviews through changes in interactive cognitions. Teaching and Teacher Education, 23(4), 457-472. http://dx.doi.org/10.1016/j.tate.2006.12.014

Schön, D. A. (1983). The reflective practitioner: How professionals think in action. New York: Basic Books.

Tyler, R. W. (1949). Basic principles of curriculum and instruction. Chicago: University of Chicago Press.

Weinstein, C., \& Mignano, A, Jr. (1993). Elementary classroom management: Lessons from research and practice. New York: McGraw-Hill.

Yinger, R. J. (1980). A study of teacher planning. The Elementary School Journal, 80(3), 107127. http://dx.doi.org/10.1086/461181

Yinger, R. J., \& Hendricks-Lee, M. S. (1998). Teacher planning, Approaches to. In T. Husén, T. N. Postlethwaite, B. R. Clark \& G. Neave (Eds.), Education: The complete encyclopedia on CD-ROM: Elsevier Science Ltd. 


\section{Lisa. Õppetöö planeerimist kajastavad märksõnad Gage'i ja Berlineri mudeli õpetamisülesannete (1998) ja õppetöö kolmeetapilises mudelis kajastuva praktilise teadmise valguses}

\begin{tabular}{|c|c|c|c|c|}
\hline \multirow{2}{*}{\multicolumn{2}{|c|}{$\begin{array}{c}\text { Gage'i ja Berlineri mudelis } \\
\text { kajastatud õpetamis- } \\
\text { ülesanne }\end{array}$}} & \multicolumn{3}{|c|}{ Praktiline teadmine (praktiline ja teoreetiline teadmine*) } \\
\hline & & \multirow[b]{2}{*}{\begin{tabular}{|l}
\multicolumn{1}{|c}{ Planeerimisetapp } \\
Õppetöö eesmärgistamise \\
oskus \\
Normatiivsed dokumendid* \\
Oma õpilaste võimekusega \\
seotud varasem kogemus \\
Õpetaja kujutlus enda kui \\
kasvataja/õpetaja rollist \\
Eelmise tunni kogemus
\end{tabular}} & \multirow{2}{*}{$\begin{array}{l}\text { Realiseerimisetapp } \\
\text { Eesmärgid täidetakse } \\
\text { või jäävad (osaliselt) } \\
\text { täitmata } \\
\text { Ettenägemisvõime } \\
\text { kohanduda oludele }\end{array}$} & \multirow[b]{2}{*}{\begin{tabular}{|l|} 
Reflekteerimisetapp \\
Kogemuse \\
arvestamine edasisel \\
planeerimisel \\
Vajaduse korral \\
püstitatud \\
eesmärkide \\
modifitseerimine \\
(otsene sisend \\
planeerimisfaasi)
\end{tabular}} \\
\hline \multirow{2}{*}{ 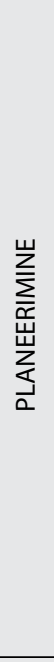 } & $\begin{array}{l}\text { Eesmärkide } \\
\text { määratlemine }\end{array}$ & & & \\
\hline & $\begin{array}{l}\text { Õpilaste/klassi eripära } \\
\text { arvestamine }\end{array}$ & $\begin{array}{l}\text { Teadmised } \\
\text { arengupsühholoogiast, õpilaste } \\
\text { sotsiaalsest, kõlbelisest ja } \\
\text { füüsilisest arengust* } \\
\text { Oma õpilaste tundmine nii } \\
\text { individuaalsel kui ka rühma } \\
\text { tasandil } \\
\text { Õpetaja hoiakud õpilaste } \\
\text { suhtes } \\
\text { Eelmise tunni kogemus }\end{array}$ & $\begin{array}{l}\text { Õpilaste eripäraga } \\
\text { arvestamine või } \\
\text { mittearvestamine } \\
\text { Õpetaja paindlikkus } \\
\text { alternatiivideks } \\
\text { olenevalt õpilas(t)e } \\
\text { käitumisest } \\
\text { Ettenägemisvõime } \\
\text { kohanduda oludele }\end{array}$ & $\begin{array}{l}\text { Vahetu kogemuse } \\
\text { arvestamine } \\
\text { edaspidisel } \\
\text { planeerimisel }\end{array}$ \\
\hline \multirow{2}{*}{ 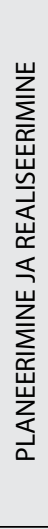 } & $\begin{array}{l}\text { Õppimise ja } \\
\text { motivatsiooni } \\
\text { mõistmine ning } \\
\text { saadud teadmiste } \\
\text { rakendamine }\end{array}$ & $\begin{array}{l}\text { Teadmised soodsa } \\
\text { õpikeskkonna kujundamisest, } \\
\text { distsipliinist ja selle } \\
\text { alalhoidmisest* } \\
\text { Varasem kogemus, kuidas klassi } \\
\text { häälestada õppimisele } \\
\text { Oskus kehtestada töökord ja } \\
\text { reeglid } \\
\text { Eelmise tunni kogemus } \\
\end{array}$ & $\begin{array}{l}\text { Tunnis korra tagamine } \\
\text { või mittetagamine } \\
\text { Õpetaja valmisolek } \\
\text { kasutada alternatiive } \\
\\
\end{array}$ & $\begin{array}{l}\text { Mälestus tunni } \\
\text { sündmustest ei } \\
\text { jää edaspidisel } \\
\text { planeerimisel } \\
\text { kajastamata }\end{array}$ \\
\hline & $\begin{array}{l}\text { Õppemeetodite } \\
\text { väljavalimine ja } \\
\text { rakendamine }\end{array}$ & $\begin{array}{l}\text { Teadmised õppemeetodite } \\
\text { mitmekesisusest* } \\
\text { Varasem kogemus tõhusatest } \\
\text { õppemeetoditest } \\
\text { Oma õpilaste tundmine } \\
\text { Eelmise tunni kogemus }\end{array}$ & $\begin{array}{l}\text { Meetod töötab või ei } \\
\text { tööta } \\
\text { Õpetaja valmisolek } \\
\text { kasutada erinevaid } \\
\text { alternatiive }\end{array}$ & $\begin{array}{l}\text { Tunni kordamineku } \\
\text { arvestamine } \\
\text { edaspidisel } \\
\text { planeerimisel }\end{array}$ \\
\hline 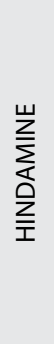 & $\begin{array}{l}\text { Õpitulemuste } \\
\text { hindamine }\end{array}$ & $\begin{array}{l}\text { Teadmised erinevatest } \\
\text { hindamisliikidest } \\
\text { (formaalne, mitteformaalne), } \\
\text { kontrollvahenditest* } \\
\text { Kogemuse pöhjal otsustamine } \\
\text { õpilaste õpiedukuse üle } \\
\text { Oma töö hindamine } \\
\text { Väljakujunenud } \\
\text { hindamissüsteem } \\
\text { Eelmise tunni kogemus }\end{array}$ & & $\begin{array}{l}\text { Planeerimise } \\
\text { korrigeerimine } \\
\text { realiseeritu ja kogetu } \\
\text { põhjal }\end{array}$ \\
\hline
\end{tabular}




\title{
Modelling instructional planning skills and developing a questionnaire for their investigation
}

\author{
Ingrid Koni $^{\mathbf{a}}{ }^{\text {, Edgar Krull }}{ }^{\mathbf{a}}$ \\ ${ }^{a}$ University of Tartu, Institute of Education
}

\section{SUMMARY}

Instructional planning is one of the most essential skills needed for professional teaching. It calls for significant theoretical as well as for practical knowledge. However, uncovering of strategies, models and skills that teachers use when planning instruction or lessons has turned out to be a rather difficult task for researchers. One of the main reasons is the complicated nature of the planning process itself. It means that teachers do not follow similar models when planning and real classroom interaction is often unpredictable and therefore fully not planned (Yinger \& Hendrics-Lee, 1998). This is the reason why practice of written lesson plans is not common for experienced teachers (Kansanen, 1981). Planning frames the broad outlines of what is possible or likely to occur when teaching but once interaction begins, planning moves to the background and instructional improvisation becomes more important (Yinger \& Hendrics-Lee, 1998).

The aim of the present study was to develop a reliable method and a data collection instrument for investigating teachers' instructional planning skills in Estonian school conditions. Investigation of the differences between beginning and experienced teachers will create opportunities to support student teachers' instructional planning skills. The authors define instructional planning from two aspects (Clark \& Yinger, 1987): firstly, from temporal aspect, which allows us to see planning from the perspectives of short-term and long-term planning. Short-term planning includes daily planning for every lesson and long-term planning indicates planning for a year, i.e. for a course as a whole. Secondly, we recourse on an idea, that planning is also concerned with setting up the physical environment and establishing the social system of the classroom.

But in order to develop a questionnaire, as a data collection instrument, a theoretical framework had to be proposed. There are many different ways to explain and model instructional planning as a process. One possible way

Institute of Education, Faculty of Social Sciences and Education, University of Tartu, Salme 1a, 50103 Tartu, Estonia, ingrid.koni@ut.ee 
to define it is to differentiate three phases in teachers' work - instructional planning, implementation and evaluation. In addition to these three phases it is possible to draw on different theoretical instructional models that many researchers have proposed. These help teachers to plan lessons and see the instructional process as a whole. In last few decades, researchers have used teachers' practical knowledge as a main theoretical conception for investigating teachers' knowledge, skills and therefore also instructional planning. The conception of teacher practical knowledge helps to describe what teachers think and know about their subject and how they modify this knowledge into real classroom activities. Therefore, in order to identify instructional planning as a process, we used three major theoretical conceptions - three phases of teacher instruction (Eggen \& Kauchak, 2013), model of five primary tasks of instruction proposed by Gage and Berliner (1998) and teachers' practical knowledge (Meijer, Verloop, \& Beijaard, 1999).

According to the conception of three phases of instruction, the first phase that teacher has to take into consideration is instructional planning. It is followed by phases of implementation and evaluation (Eggen \& Kauchak, 2013). Besides evaluating students, the latter phase also includes teacher reflection on one's own practice. But in order to understand instructional planning as a process in more detail, we relied also on Gage and Berliner's (1998) model of five primary tasks of instruction, that suggest teacher to a) choose objectives, b) understand student characteristics, c) understand and use ideas about the nature of learning and motivation, $d$ ) select and use ways of teaching (methods, strategies) and e) evaluate student learning. This model helps to uncover all the primary knowledge and skills needed for instruction and it is also suitable for daily planning as well as for long-term planning. Since in real classroom instruction the task of choosing objectives follows after evaluation procedure, this model describes instruction as a cyclical process.

One step further in the process of defining instructional planning is to elaborate this conception through the notion of teacher practical knowledge. The merit of this conception stems from the point that it helps to understand the knowledge base that teachers need for instruction (Meijer et al., 1999). Although many different researchers have defined the teacher practical knowledge from various points of view and with various assumptions, we relied on Meijer and her colleagues definition (1999) that is based on a review of different studies of teachers' practical knowledge. They define practical knowledge ,as the knowledge and beliefs that underlie his or her actions; this kind of knowledge is personal, related to context and content, often tacit, and based on (reflection on) experience" (p 60).

Teachers' practical knowledge consists of two type of knowledge (Schön, 1983): knowledge and beliefs on the one hand and interactive cognitions on the other hand. Knowledge and beliefs are defined as the frame of reference with 
which practice is perceived and interactive cognitions are teachers' thoughts when teaching. Interactive cognitions are related to the actual behaviour of teachers, they link the knowledge and beliefs of teachers with teachers' actions. This relation is explained with two types of memory, the short- and long-term memory (Meijer, Verloop, \& Beijaard, 2002). Knowledge and beliefs of teachers are stored in long-term memory, interactive cognitions are stored in short-term memory. Different instructional situations activate knowledge in long-term memory, which in turn activate this knowledge temporarily in short-term memory and therefore it's the basis for teacher actions. As regards to the three phases of instruction, teachers use practical knowledge differently in each phase (Krull \& Raudsepp, 2010). In the phase of planning and evaluation, teachers use knowledge and beliefs that derive from theoretical and practical studies. In the phase of implementation dominate teachers' interactive cognitions that represent ready-to-use behavioural patterns.

In order to develop a theoretical model for instructional planning and to unfold its components, we combined the model of five primary tasks of instruction proposed by Gage and Berliner (1998) with the conception of teachers' practical knowledge that is presented in three phase of instruction. Reasons why we used these theoretical models are that firstly, the model proposed by Gage and Berliner allows to describe and systematize different knowledge areas needed for instructional planning. Secondly, using the conception of teachers' practical knowledge in a three phases of instruction gives Gage and Berliner's model more practical input, leading attention to the interconnectedness of these three phases.

As a result of defining the theoretical framework for instructional planning, a questionnaire was developed based on it. It comprises of five major topics: a) choosing objectives, b) understanding student characteristics, c) understanding and using ideas about the nature of learning and motivation, d) selecting and using ways of teaching (methods, strategies) and e) evaluating student learning. Every topic includes questions about three phases of instruction, since they are all connected. Furthermore, questions about planning include questions on short-term and long-term planning as well as planning for setting up the physical environment and establishing the social system of the classroom.

The questionnaire consists of questions on the respondents' background data and of 35 questions and issues of instructional planning. Questions about instructional planning are presented in the form of 5-point Likert-type scales where the subjects have to express how much they agree or disagree with a particular statement.

Keywords: instructional planning, modelling of instructional planning, teacher education, beginning and expert teachers 